\title{
Elaborating a scheme for mine methane capturing while developing coal gas seams
}

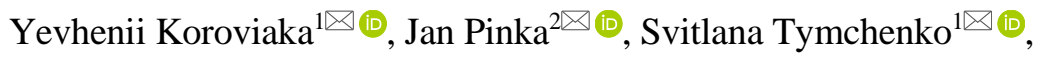

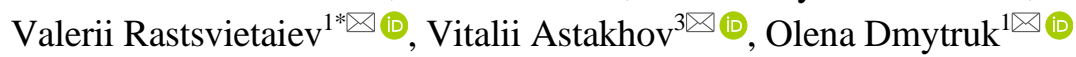 \\ ${ }^{1}$ Dnipro University of Technology, Dnipro, 49005, Ukraine \\ ${ }^{2}$ Technical University of Kosice, Kosice, 04200, Slovakia \\ ${ }^{3}$ LLC “Avior-Dnipro”, Dnipro, 49033, Ukraine \\ *Corresponding author: e-mail rastsvietaiev.v.o@nmu.one, tel.+380563730754
}

\begin{abstract}
Purpose is to substantiate and develop an efficient scheme of coalmine methane capture while preparing and developing gassy coal seams.

Methods. Critical analysis of literature sources has been carried out; practice of applying the known schemes of coalmine methane capture for its further use has been systematized. Analysis and selection of theoretical substantiation of a new coalmine methane capture scheme have been performed taking into consideration the parameters of preparation and development of gassy coal seams. Methods of mathematical analysis have been applied to describe the dependence of gamma distribution of the continuous random variable of gas emission intensity on the distance to a stope.

Findings. A scheme of coal mass degassing has been improved; that scheme helps increase degassing degree and eliminate colliery gas, including methane, in terms of specific arrangement of wells and introduction of new technological operations and parameters. The developed scheme takes into consideration physical and mathematical properties of rocks to increase the volume of produced gas along with the reduced total mining costs. Mathematical modeling has made it possible to define that the density function coincides maximally with the experimental and practical graph of dependence of gas emission intensity on the distance to a stope.

Originality. Analytical dependences have been specified making it possible to evaluate rational range of the depth of degassing gas outlet wells and the distance between them according to the proposed scheme of their arrangement within the extraction pillar.

Practical implications. The proposed scheme of coal mass degassing allows controlling coalmine methane extraction including special preparatory operations. It helps widen a range of effective application of the system for colliery gas extraction and reduce the time for preparatory degassing operations; that favours both rising stope output and the associated coalmine methane recovery with the corresponding increase in energy saving and safety during mining operations.
\end{abstract}

Keywords: capture, methane, coal seam, degassing, coal mass, well

\section{Introduction}

Nowadays, natural gas consumption is at a high level. Since gas is extracted mostly from nonrenewable deposits, that results in the necessity to expand the exploration area and search for alternative sources [1]-[3] as well as to Improve the available extraction techniques [4]-[9] and to consider unconventional methods of gas recovery from coal and biomass [10], [11]. When gas is extracted in a traditional way, there is a need to solve the problems connected with the specific features arising in the process of drilling operations [12]-[15].

Coal seams, which development involves the equipment requiring constant improvement, may also be considered as alternative sources to extract natural gas [16], [17]. Increase in gassiness of the developed coal seams is a great difficulty for efficient use of such heavy-duty facilities in production and development faces [18]-[21]. Growth of air supply to the production development sites is limited by such parameter as boundary admissible air rate and economically expedient areas of mine working cross sections. Owing to those facts, procedures aimed at prevention, decrease, or redistribution of mine methane emissions within the mine working during certain technological processes (gas control methods) are widely used in coal mines [22]-[24]. The methods include gas control, mining and engineering facilities control, ventilation facilities control, and degassing facilities control.

Ventilation of mine working is the basic method of methane recovery from the coal mines. Despite the fact that 
methane dilution in a mine requires the air supply being 10-20 times more than the amount of the extracted coal, nowadays, it is not enough to reduce methane concentration within the mine working down to the safe level [25]-[27]. Under such conditions, methods of forced degassing of main gas-emission sources (coal seams, rocks, and worked-out areas) are applied - the methods mean methane pumping out [28]. However, despite their high cost, even complex use of several methods to control methane in a mine cannot always provide safe level of methane concentration.

\section{Literature review}

There are numerous schemes to capture mine methane. As a rule, they involve various degassing techniques while developing gassy coal seams. Selection of degassing technique while developing gassy coal seams of various thicknesses depends upon different factors in terms of a certain case. The factors include natural coal and lateral rock gassiness, direction of fissility, natural seam pressure of the gas, sorption and filtration properties, and the adopted system of development.

In terms of stoping, preliminary or accompanying degassing with various types of coal seam effecting is applied [29]. Main feature of preliminary degassing is in the fact that to increase gas recovery factor, the coal mass should be effected in more energy-intensive way. In its turn, that has negative influence upon economic efficiency of a mining enterprise [30], [31].

Accompanying degassing makes it possible to use the results of manifestation of natural dynamic processes in the rock mass caused by mining operation development as well as to predict more accurately the dynamics of formation of gas accumulation areas, intensity of its emission into the face zone, worked-out area, and development entries of the working area.

Intensity of methane emission from the developed seam while its breaking depends upon the extraction pattern, type of actuating device of an extracting machine, shearer feed rate, longwall length and other factors. In this context, as a rule, greatest methane accumulation within the face zone is observed near the conveyor.

Branch institutions propose typical schemes for seam degassing stipulating advance drilling of degassing wells from the development mine workings [29]. It should be noted that following parameters are rather important conditions for degassing efficiency: well length, distance between wells, their diameters etc.

It should be highlighted that in most cases the major share of the emitted mine methane is accounted for the worked-out area within the extraction pillar [32]-[34]. Thus, the problem of its capturing is still topical while developing coal reserves.

The problem is especially urgent in terms of possible methane capturing within the operating mines with great amount of its commercial reserves [35], [36]. There can be given an example of methane emission values in terms of mines of PJSC "DTEK Pavlohradvuhillia"; the values, represented in Table 1, are rather characteristic for the majority of Ukrainian coal mining enterprises.

In this context, Table 2 represents indices of gas balance of the working area being characteristic for the majority of coal mining enterprises of Ukraine.
Table 1. Indices of average methane content in the operating mines of PJSC "DTEK Pavlohradvuhillia"

\begin{tabular}{lcc}
\hline \multicolumn{1}{c}{ Name of a mine } & $\begin{array}{c}\text { Rating } \\
\text { of gas hazard }\end{array}$ & $\begin{array}{c}\text { Methane } \\
\text { content, } \mathrm{m}^{3} / \mathrm{t}\end{array}$ \\
\hline Blahodatna & 3 & 14.0 \\
Heroiiv Kosmosu & $\mathrm{C}$ & 18.7 \\
Dniprovska & 3 & 9.8 \\
Zakhidno-Donbaska & $\mathrm{C}$ & 22.1 \\
Pavlohradska & 3 & 13.2 \\
Samarska & 3 & 13.7 \\
Stashkova & 2 & 6.7 \\
Stepova & $\mathrm{C}$ & 23.7 \\
Ternivska & $\mathrm{C}$ & 15.0 \\
Yuvileina & 3 & 10.7 \\
\hline
\end{tabular}

Table 2. Gas balance of the working area

\begin{tabular}{lcc}
\hline \multirow{2}{*}{ Methane release sources } & \multicolumn{2}{c}{ Average expected methane emission } \\
\cline { 2 - 3 } & relative, $\mathrm{m}^{3} / \mathrm{t}$ & absolute, $\mathrm{m}^{3} / \mathrm{min}$ \\
\hline Loosened coal, $q_{o . y}$ & 4.04 & 5.62 \\
Loosened coal & 2.09 & 2.90 \\
in long wall, $q^{\prime}$ o.y & 3.90 & 5.42 \\
Production face, $q_{o . n}$ & 7.91 & 10.98 \\
Enclosing rocks, $q_{n o p}$ & 27.07 & 37.60 \\
Seams being & & \\
underworked, $q_{c n . n}$ & 8.66 & 12.03 \\
Seams being & & \\
developed, $q_{s e}$ & 3.07 & 4.26 \\
Seams being & 38.76 & 53.83 \\
overworked, $q_{c n . n}$ & 9.26 & 12.86 \\
Worked-out area, $q^{\prime}$ b.n & 44.75 & 62.15 \\
Stope face, $q_{s p}$ & & \\
Working area, $q_{a r}$ & &
\end{tabular}

Analyzing the expression to determine the expected methane emission from the worked-out area $\left(q_{b . n}^{\prime}\right)$, according to [37], it may be concluded that there are following sources from which methane comes into the worked-out area:

- coal loosened from the developed seams and left within the worked-out area;

- seams being overworked;

- seams being underworked;

- enclosing rocks of the rock mass.

Taking into account the fact that practically all the methane from the mentioned sources comes into the worked-out area, degassing is still one of the most important measures in terms of methane capturing within the limits of the working area.

Considering the aforementioned, there is the necessity to develop efficient scheme to capture coalmine methane; it is especially topical in terms of the development of the reserves of gassy coal mines.

The proposed scheme of coal rock mass degassing deals with the issues of mining operation safety in coal mines as well as methane capturing and its recovery; the scheme may be used while stoping operations.

There is a well-known method of coal rock mass degassing involving the construction of additional mine working - collector. The working is driven above the coal seams along the whole extraction pillar length behind the zone of active displacements of main roof; that is the basis to form separate gascollecting level. To do that, the mine working floor should have a ring of wells dividing the site into sub-sites, uniting the degassing system, and performing degassing operations by forced gas withdrawal into the wells, drilled from the surface, into the collector and the seam being developed [38]. 
Disadvantage of the technique is in the complexity of that degassing system and the construction of additional mine working, acting as a collector, with a complex system of degassing wells.

There is also additional degassing technique when degassing wells are drilled from the mother gate to access the roof rock; the wells are drilled above the coal seam throughout the extraction pillar length with the degassing wells displacement towards zonal mine working. That is, the wells are located along the zonal mine working at small distance from its axis [39].

Disadvantage of the method is in its insufficient level of coal rock mass degassing with consequent unproductive gas recovery.

There is also the degassing technique where horizontal degassing wells are drilled from the zonal mine working to access the roof rocks; the wells are drilled above the coal seam in parallel to the production face at the distance being 0.5-1.0 $\mathrm{m}$ from the seam [29]. Disadvantage of the method is in low level of coal rock mass degassing; thus, the technique is low efficient as for gas recovery.

The proposed scheme of wells construction has the following basis: a task to improve degassing of coal rock mass when innovative operations and parameters are introduced to increase the degassing degree (including methane removing) with the possibility to take into consideration physical and mechanical properties of rocks. The process results in further growth of the extracted gas output along with the decreased total costs for mineral extraction [40].

\section{Methods}

The problem is solved as follows. According to the wellknown coal rock mass degassing technique, horizontal degassing wells are drilled within the rock mass; the wells access the seam roof rocks throughout the pillar length in parallel to the zonal mine workings with return ventilation air. According to the proposed scheme, horizontal degassing wells are drilled within relatively stable roof rocks in the central part of the extraction pillar; a set of wells is drilled in controlled drilling from them towards the coal seam into the zone of active stratification of the main roof forming a gascollecting level from which degassing is performed by forced mine gas recovery.

Figure 1 demonstrates the proposed technique explained by the scheme of coal rock mass degassing to recover coalmine gas. When preparation work to form extraction pillar is completed (Fig. 1), i.e. there are structures of development zonal mine workings 2 and 4 as well as installation chamber of production face 3 , horizontal degassing wells 5 are drilled from mother entry 1 . Further, a set of vertical degassing wells 6 are drilled from the horizontal degassing wells 5 towards coal seam 8 . All the wells supply captured gas into gas pipe of mother entry 7 .

Depending upon physical and chemical properties of roof rocks, one or several horizontal degassing wells 5 may be drilled within the area of extraction pillar. Total amount of horizontal degassing wells is calculated for specific mining conditions taking into consideration properties of the roof rocks.

Calculation of the parameters of engineering process as well as preliminary construction and putting into service of all the degassing wells before stoping operations is a compulsory condition. (a)

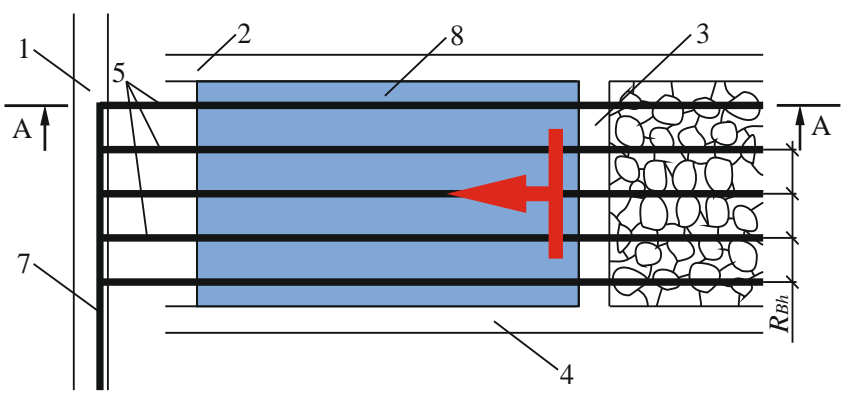

(b)

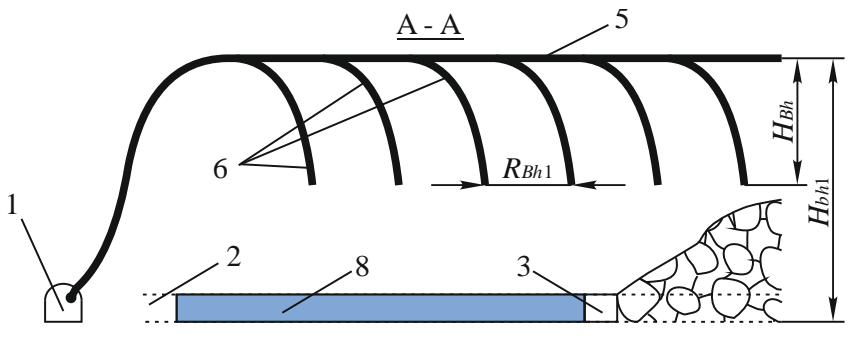

Figure 1. Scheme of coal rock mass degassing to recover coalmine gas: (a) top view; (b) cross section view $A-A$; 1 - mother entry; 2 - zonal mine working with intake air; 3 - production face (installation chamber) 4-zonal mine working with return ventilation air; 5 - horizontal degassing wells being drilled from the mother entry; 6 - set of degassing wells towards the coal seam being drilled from horizontal degassing wells; 7 - gas pipe in the mother entry; 8 -coal seam

\section{Results and discussion}

When reserves of coal mine 8 are extracted, within the area of extraction pillar, production face 3 moves constantly with the rate being usually calculated for specific mining conditions. In terms of constant movement of production face 3 above the coal seam, within the area of extraction pillar, rock is broken and stratifies forming gas-collecting level; that favours activation of natural process of mine gas emission, i.e. methane emission. There is conventional division into separate active zones of gas-collecting level formation within certain areas creating additional surfaces for mine gas (i.e. methane) emission from associated seams and rocks containing working layer; that favours general methane capturing. Formation of such local zones of methane accumulation creates the conditions for efficient mine gas (i.e. methane) recovery within the zones of mining operations.

Layout parameters of degassing wells 5 and 6 , in particular, distances $H_{b h}, H_{b h 1}, R_{b h}$, and $R_{b h 1}$, as Figure 1 shows, are also calculated for specific mining conditions.

The proposed technique makes it possible to activate the process of mine gas accumulation and to control both the preset direction of mine gas within the extraction pillar limits and its capturing.

Since gas capturing starts after underworking of wells by a stoping face when production face shifts from the well, then, according to [41], gas emission process may be evaluated by function:

$q=a x e^{-b x}$,

where: 
$x$ - a distance from the production face;

$a, b$-coefficients depending upon the specific mining and engineering conditions.

Figure 2 demonstrates a graph of gas emission intensity dependence upon the distance to a production face where $q$ is gas emission intensity and $x$ is distance to production face.

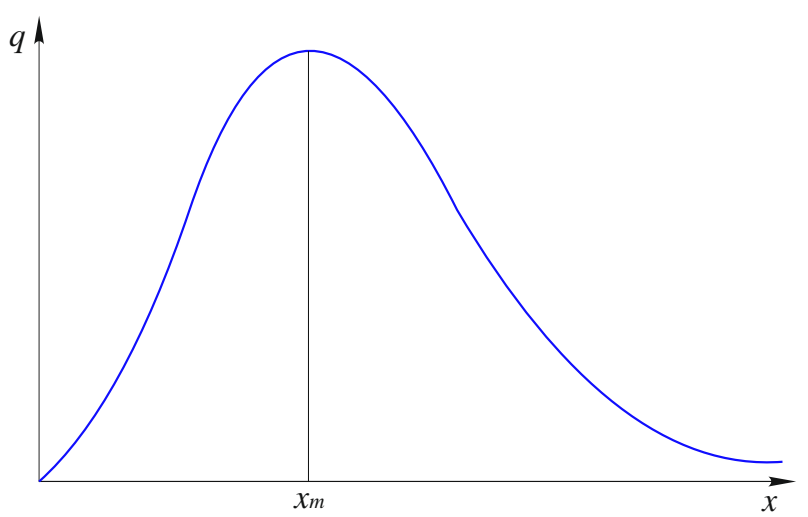

Figure 2. Dependence of gas emission intensity upon the distance to production face

Owing to the fact that the formula is obtained as a generalized numerous practical and experimental data, it may be considered as the approximating envelope curve of general totality and analyzed according to similar statistic regularities represented in papers [42]-[44].

Comparing expression (1) and graph in Figure 2 with the formula and graphs of gamma distribution of continuous random value, it may be assumed that the dependence can be described by gamma distribution with $\alpha=2$ parameter represented in Figure 3.

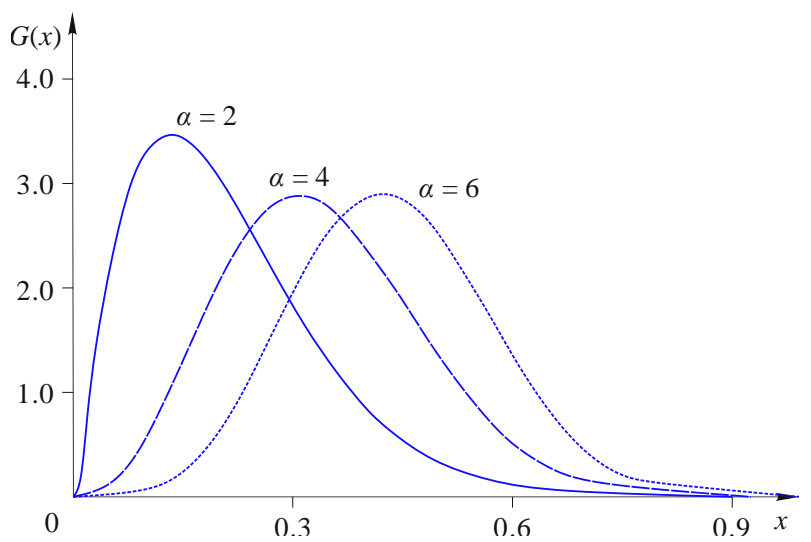

Figure 3. Functions of gamma distribution density in terms of various $\alpha$

According to the modeling results demonstrated in Figure 2, it has been determined that, in terms of $\alpha=2$ value, functions of gamma distribution density coincide maximally with the experimental and practical graph of gas emission dependence upon the distance to production face. In this context, it is required to take into account the fact that the probability density in terms of gamma distribution is specified by expression:

$f(x)=\left\{\begin{array}{l}0 \text { if } x \leq 0, \\ \frac{\beta^{a}}{G(a)} x^{a-1} e^{-\beta x},\end{array}\right.$ where:

$\alpha, \beta>0$

$G(a)$-gamma Euler function: $\left(\Gamma(a)=\int_{0}^{\infty} x^{a-1} e^{-x} d x\right)$.

Then, according to the above-mentioned: $G(2)=\int_{0}^{\infty} x^{2-1} e^{-x} d x=\int_{0}^{\infty} x e^{-x} d x=-x e^{-x}-e^{-x}:_{0}^{\infty}=1$.

In this case, mathematical expectation is:

$M(X)=x_{m}=\int_{0}^{\infty} x f(x) d x=\frac{a G(\alpha)}{\beta G(\alpha)}=\frac{a}{\beta}=\frac{2}{\beta}$.

Under such conditions, dispersion will be determined as:

$D(x)=\int_{0}^{\infty} x^{2} f(x) d x-M^{2}(x)=\frac{\alpha}{\beta^{2}}=\frac{2}{\beta^{2}}$.

While mean-square deviation is:

$\sigma=\sqrt{D(x)}=\sqrt{\frac{\alpha}{\beta^{2}}}=\frac{\sqrt{2}}{\beta}$.

Having compared all the aforementioned, in our case, expression (1) will be as follows:

$q=\beta^{2} x e^{-\beta x}$

Taking into consideration expression (3) $\beta=\frac{2}{x_{m}}$, in this case formula (1) may be represented as follows:

$q=\frac{4}{x_{m}^{2}} x e^{\frac{-2 x}{x_{m}}}$

Herewith, $q_{m}$ is maximum intensity of gas emission corresponding to value $x_{m}$ - being equal to mathematical expectation of the distance to production face which can be determined by following expression:

$q_{m}=\frac{4}{x_{m} e^{2}}$

Basing upon the theoretical studies, the coefficients may be represented by interval and may be taken according to specific mining-geological and mining-engineering conditions.

It should be noted that value $x_{m}$ determined by mathematical modeling is 2 times more and value $q_{m}$ is 1.47 times more than in the case when methods of mathematical analysis are applied for formula (1) (calculation of a derivative and its equating to zero to find extremum point). In this context, according to [42] it is pointed out that comparability of the results obtained with the help of mathematical analysis methods with real practical data is from 30 to 50\%. Thus, accuracy of the mentioned statistic approach differs from real practical results by not more than $20 \%$.

Taking into consideration all the above-stated facts and according to Figure 1, the ideas make it possible to evaluate rational range of depth for degassing gas removal wells $H_{b h}$ or $x$ and determine depth $x_{m}$ corresponding to maximum gas recovery. Another important parameter for that methane capturing technique is the step between removal wells $R_{b h 1}$. 
Degassing wells may operate efficiently in terms of certain interval of distances from production face $\left(H_{b h 1}\right)$; in terms of the considered case, it is assumed that gas recovery from a removal degassing well follows normal law of distribution (Fig. 4). Then, $m$, mathematical expectation, coincides both with the center of distribution and gas removal well with $x_{m}$ depth.

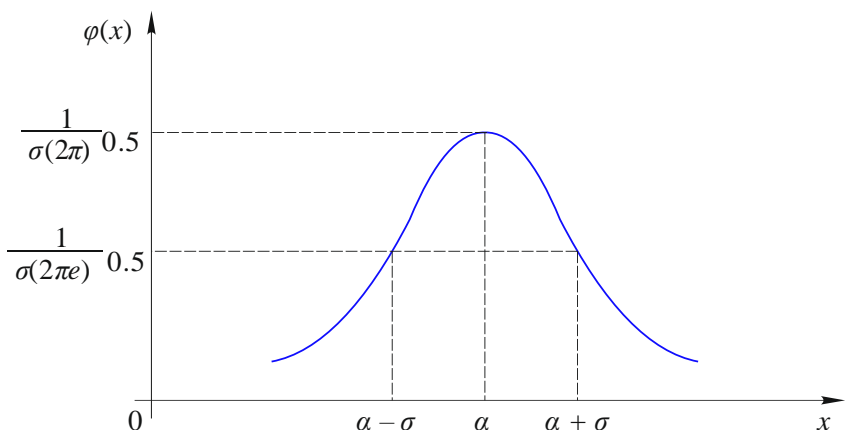

Figure 4. Graph of probability density in terms of normal distribution

Thus, $m=a=0$ and value of mean-square deviation will be determined basing upon the fact that if $x=m$, then maximum gas recovery is observed being equal to $q_{m}=\frac{4}{x_{m} e^{2}}$.

Taking into consideration that $q_{m}=\frac{4}{x_{m} e^{2}}=\frac{1}{\sigma \sqrt{2 \pi}}$, we obtain:

$$
\sigma=\frac{1}{q_{m} \sqrt{2 \pi}}=\frac{x_{m} e^{2}}{4 \sqrt{2 \pi}}
$$

In case of normal distribution, up to $95 \%$ of random value fall into the specified interval $[m-2 \sigma ; m-2 \sigma]$. The interval width is $4 \sigma$ being equal to the required value $R_{b h 1}$. Thus:

$$
R_{b h 1}=4 \sigma=\frac{x_{m} e^{2}}{\sqrt{2 \pi}} \approx 2.95 x_{m} \approx 3 H_{b h} .
$$

\section{Conclusions}

The proposed technological scheme for coal rock mass degassing makes it possible to control immediately the process of mine methane recovery including special preparatory operations. When technological process of coal rock mass degassing is simplified, there is the possibility of its control and expansion of the area of efficient application of the system to extract mine gas along with the decrease in time to perform preparatory operations for degassing. That favours both increasing per face output and accompanying mine gas recovery; thus, energy saving and safety of mining operations increase.

\section{Acknowledgements}

The research has been supported by the Ministry of Education and Science of Ukraine via research grant No. 0120U102084 and carried out by Dnipro University of Technology and Technical University of Kosice, Institute of Earth's Resources (Slovakia). We express gratitude to our colleagues from our institutions who provide us with the required information and helped considerably complete the research.

\section{References}

[1] Korovyaka, Ye.A., Vasilenko, Ye.A., \& Manukyan, E.S. (2014) Regeneration of methane released from landfills, and possibility of its utilization in Dnipropetrovs'k region. Heotekhnichna Mekhanika, (117), 215-224.

[2] Korovyaka, Ye., Astakhov, V., \& Manukyan, E. (2014). Perspectives of mine methane extraction in conditions of Donets'k gas-coal basin. Progressive Technologies of Coal, Coalbed Methane, and Ores Mining, 311-316.

[3] Koroviaka, Ye., Rastsvietaiev, V., Dmytruk, O., \& Tykhonenko, V. (2017). Prospects to use biogas of refuse dams of Dnipropetrovsk region (Ukraine) as alternative energy carrier. Mechanics, Materials Science \& Engineering, (11), 1-9. https://doi.org/10.2412/mmse.40.34.18

[4] Medunić, G., Mondol, D., Rađenović, A., \& Nazir, S. (2018). Review of the latest research on coal, environment, and clean technologies. Rudarsko Geolosko Naftni Zbornik, 33(3), 13-21. https://doi.org/10.17794/rgn.2018.3.2

[5] Zubkova, V., Strojwas, A., Bielecki, M., Kieush, L., \& Koverya, A. (2019). Comparative study of pyrolytic behavior of the biomass wastes originating in the Ukraine and potential application of such biomass. Part 1. Analysis of the course of pyrolysis process and the composition of formed products. Fuel, (254), 115688. https://doi.org/10.1016/j.fuel.2019.115688

[6] Nosić, A., Karasalihović Sedlar, D., \& Jukić, L. (2017). Oil and gas futures and options market. Rudarsko Geolosko Naftni Zbornik, 32(4), 45-54. https://doi.org/10.17794/rgn.2017.4.5

[7] Saik, P., Petlovanyi, M., Lozynskyi, V., Sai, K., \& Merzlikin, A. (2018). Innovative approach to the integrated use of energy resources of underground coal gasification. Solid State Phenomena, (277), 221-231. https://doi.org/10.4028/www.scientific.net/SSP.277.221

[8] Lozynskyi, V.G., Dychkovskyi, R.O., Falshtynskyi, V.S., Saik, P.B., \& Malanchuk, Ye.Z. (2016). Experimental study of the influence of crossing the disjunctive geological faults on thermal regime of underground gasifier. Naukovyi Visnyk Natsionalnoho Hirnychoho Universytetu, (5), 21-29.

[9] Bondarenko, V., Lozynskyi, V., Sai, K., \& Anikushyna, K. (2015). An overview and prospectives of practical application of the biomass gasification technology in Ukraine. New Developments in Mining Engineering 2015: Theoretical and Practical Solutions of Mineral Resources Mining, 27-32. https://doi.org/10.1201/b19901-6

[10] Kieush, L. (2019). Coal pyrolysis products utilisation for synthesis of carbon nanotubes. Petroleum and Coal. 61(3), 461-466

[11] Kieush, L., Yaholnyk, M., Boyko, M., Koveria, A., \& Ihnatenko, V. (2019). Study of biomass utilisation in the iron ore sintering. Acta Metallurgica Slovaca, 25(1), 55. https://doi.org/110.12776/ams.v1i1.1225

[12] Dudlia, M., Pinka, J., Dudlia, K., Rastsvietaiev, V., \& Sidorova, M. (2018). Influence of dispersed systems on exploratory well drilling. Solid State Phenomena, (277), 44-53. https://doi.org/10.4028/www.scientific.net/SSP.277.44

[13] Dudlia, M., Sirik, V., Rastsvetaev, V., \& Morozova, T. (2014). Rotary drilling system efficiency reserve. Progressive Technologies of Coal, Coalbed Methane, and Ores Mining, 123-129.

[14] Sidorova, M., Cizek, P., Galant, Y., \& Pinka, J. (2017). New thoughts on the prospects of petroleum potential in the eger rift. Archives of Mining Sciences, 62(1), 203-214. https://doi.org/10.1515/amsc-2017-0015

[15] Sudakov, A., Dreus, A., Kuzin, Y., Sudakova, D., Ratov, B., \& Khomenko, O. (2019). A thermomechanical technology of borehole wall isolation using a thermoplastic composite material. E3S Web of Conferences, (109), 00098. https://doi.org/10.1051/e3sconf/201910900098

[16] Bondarenko, V.I., Kharin, Ye.N., Antoshchenko, N.I., \& Gasyuk, R.L. (2013). Basic scientific positions of forecast of the dynamics of methane release when mining the gas bearing coal seams. Naukovyi Visnyk Natsionalnoho Hirnychoho Universytetu, (5), 24-30.

[17] Bondarenko, V., Tabachenko, M., \& Wachowicz, J. (2010). Possibility of production complex of sufficient gasses in Ukraine. New Techniques and Technologies in Mining, 113-119. https://doi.org/10.1201/b11329-19

[18] Pivnyak, G., Dychkovskyi, R., Bobyliov, O., Cabana, E.C., \& Smoliński, A. (2018). Mathematical and geomechanical model in physical and chemical processes of underground coal gasification. Solid State Phenomena, (277), 1-16. https://doi.org/10.4028/www.scientific.net/ssp.277.1

[19] Zapletal, P., Koudelková, J., Zubíček, V., Král, T., \& Mokrošová, A. (2018). A new method of gas drainage as a solution for dangerous phenomena in underground coal mines. Rudarsko Geolosko Naftni Zbornik, 33(1), 7-12. https://doi.org/10.17794/rgn.2018.1.2

[20] Pivnyak, G., Bondarenko, V., Kovalevs'ka, I., \& Illiashov, M. (2012). Geomechanical Processes during Underground Mining. London, United Kingdom: CRC Press, Taylor \& Francis Group. https://doi.org/10.1201/b13157 
[21] Bondarenko, V., Symanovych, G., \& Koval, O. (2012). The mechanism of over-coal thin-layered massif deformation of weak rocks in a longwall. Geomechanical Processes during Underground Mining, 4144. https://doi.org/10.1201/b13157-8

[22] Pivnyak, G.G., \& Shashenko, O.M. (2015). Innovations and safety for coal mines in Ukraine. Naukovyi Visnyk Natsionalnoho Hirnychoho Universytetu, (6), 118-121.

[23] Miroshkin, G.A., Polyakov, E.V., \& Marchenko, V.G. (1992). Application of mark method of measurement in instruments of speed and gas consumption control in mine workings. Fiziko-Tekhnicheskie Problemy Razrabotki Poleznykh Iskopaemykh, (5), 92-97.

[24] Denyshchenko, O.V., Shyrin, A.L., Rastsvietaiev, V.O., \& Cherniaiev, O.V. (2018). Forming the structure of automated system to control ground heavy-type ropeways. Scientific Bulletin of the National Mining University, (4), 79-85.

[25] Golinko, V., Yavors'ka, O., \& Lebedev, Y. (2011). Substantiation of the parameters of elements of mine vent systems while exploiting bedded deposits of horizontal occurence. Technical and Geoinformational Systems in Mining, 131-133. https://doi.org/10.1201/b11586-22

[26] Mukha, O., \& Pugach, I. (2014). Substantiation of ventilation parameters and ways of degassing under bleeding of methane. Progressive Technologies of Coal, Coalbed Methane, and Ores Mining, 361-366. https://doi.org/10.1201/b17547-62

[27] Muha, O., \& Pugach, I. (2011). Determination of ventilation and degassing rational parameters at extraction areas of coal mines. Technical and Geoinformational Systems in Mining, 197-200. https://doi.org/10.1201/b17547-62

[28] Kremenchutskiy, N., Muha, O., \& Pugach, I. (2012). Degassing systems rational parameters selection at coal mines. Geomechanical Processes During Underground Mining, 87-93. https://doi.org/10.1201/b13157-15

[29] SOU 10.1.00174088.001-2004. (2004). Coal mine degassing. Re quirements for methods and degassing schemes. Kiev, Ukraina: Ministerstvo uholnoi promyshlennosti Ukrainy.

[30] Law, B.E. (1998). Basin-centered gas evaluated in Dnieper-Donets basin, Donbas foldbelt, Ukraine. Oil and Gas Journal, 96(47), 74-78.

[31] Piwniak, G.G., Bondarenko, V.I., Salli, V.I., Pavlenko, I.I., \& Dychkovskiy, R.O. (2007). Limits to economic viability of extraction of thin coal seams in Ukraine. Technical, Technological and Economic Aspects of Thin-Seams Coal Mining International Mining Forum 2007, 129-132. https://doi.org/10.1201/noe0415436700.ch16

[32] Sai, K., Malanchuk, Z., Petlovanyi, M., Saik, P., \& Lozynskyi, V. (2019). Research of thermodynamic conditions for gas hydrates formation from methane in the coal mines. Solid State Phenomena, (291), 155-172. https://doi.org/10.4028/www.scientific.net/SSP.291.155
[33] Nalisko, M., Sobolev, V., Rudakov, D., \& Bilan, N. (2019). Assessing safety conditions in underground excavations after a methane-air mixture explosion. E3S Web of Conferences, (123), 01008. https://doi.org/10.1051/e3sconf/201912301008

[34] Lukinov, V., Prykhodchenko, V., Tokar, L., \& Prykhodchenko, O. (2014). Mining and geological conditions of methane redistribution within the undermined coal-rock massif. Progressive Technologies of Coal, Coalbed Methane, and Ores Mining, 317-325. https://doi.org/10.1201/b17547-55

[35] Busygin, B., \& Nikulin, S. (2013). Predicting methane accumulation in the Donetsk coal basin (Ukraine) on the basis of geological, geophysical and space data. Energy Efficiency Improvement of Geotechnical Systems, 161-167. https://doi.org/10.1201/b16355-22

[36] Bezruchko, K., Prykhodchenko, O., \& Tokar, L. (2014). Prognosis for free methane traps of structural and tectonic type in Donbas. Progressive Technologies of Coal, Coalbed Methane, and Ores Mining, 267-271. https://doi.org/10.1201/b17547-47

[37] Korovyaka, Ye.A., Manukyan, E.S., \& Vasilenko, Ye.A. (2011) Prospects of shaft methane extraction and utilization in the conditions of mine "Zapadno-Donbaskaya" OAO "Pavlogradugol". Naukovyi Visnyk Natsionalnoho Hirnychoho Universytetu, (4), 39-44.

[38] DNAOT 1.130-6.09.93. (1994). Guidance to design coal mine ventilation. Kiev, Ukraina: Osnova.

[39] Bulat, A.F., Zviahilsky, Yu.L., Lukinov, V.V., Iliushenko, V.H., Kolesnikov, V.H., Vynogradov, V.V., Humaniuk, O.M., Kyiashko, Yu.I., Bokii, B.V., Kamyshan, V.V., \& Kasymov, O.I. (2003). A technique of coal-bearing rock mass degassing. Patent No. 53259, Ukraine.

[40] Wang, Z., Ren, T., \& Zhang, L. (2011). Review of gas emission prediction and control methods for multi-seam mining in Chinese coal mines. $1^{\text {th }}$ Underground Coal Operators' Conference, University of Wollongong \& the Australasian Institute of Mining and Metallurgy, 315-325.

[41] Shyrin, L.N., Rastsvietaiev, V.O., Astakhov, V.S., Koroviaka, Ye.A., Dmytruk, O.O., Manukyan, E.S., Dudlia, K.Ye, Ganushevych, K.A., Cherniaiev, O.V., \& Hrytsenko, L.S. (2017). A technique of coalbearing rock mass degassing. Patent No. 122194, Ukraine.

[42] Morev, A.M., \& Yevseiev, I.I. (1975). Degassing of contiguous seams. Moscow, Russian Federation: Nedra.

[43] Babets, D. (2018) Rock mass strength estimation using structural factor based on statistical strength theory. Solid State Phenomena, (277), 111122. https://doi.org/10.4028/www.scientific.net/SSP.277.111

[44] Sherbakov, P.N., Klymenko, D.V., \& Tymchenko, S.E. (2017). Statistical research of shovel excavator performance during loading of rock mass of different crushing quality. Scientific Bulletin of the National Mining University, (1), 49-55.

\section{Формування схеми каптації шахтного метану при розробці газообільних вугільних пластів}

\section{Є. Коровяка, Я. Пінка, С. Тимченко, В. Расцвєтаєв, В. Астахов, О. Дмитрук}

Мета. Обгрунтування і розробка ефективної схеми каптаціі шахтного метану при підготовці та відпрацюванні багатих на газ вугільних пластів.

Методика. Виконано критичний аналіз літературних джерел і систематизації досвіду застосування відомих схем каптаціі шахтного метану для його подальшого використання. Здійснено аналіз та вибір теоретичного обгрунтування нової схеми каптаціі шахтного метану, що, зокрема, враховує показники підготовки та розробки газообільних вугільних пластів. Застосовано методи математичного аналізу для опису гамма розподілу неперервної випадкової величини інтенсивності газовиділення від відстані до очисного вибою.

Результати. Вдосконалено схему дегазації вуглепородного масиву, в якій, при певному розташуванні свердловин і введенням нових технологічних операцій та параметрів, досягається можливість підвищення ступеня дегазації й видалення шахтного газу, в тому числі газу метану. Розроблена схема враховує фізико-механічні властивості гірських порід, за рахунок чого збільшується обсяг видобутого газу при зниженні сумарних витрат на видобуток корисних копалин. Математичним моделюванням встановлено, що функція щільності розподілу газовиділення максимально збігається з експериментально-практичним графіком залежності інтенсивності газовиділення від відстані до очисного вибою.

Наукова новизна. Встановлено аналітичні залежності, що дозволяють оцінити раціональний діапазон глибини дегазаційних газовідвідних свердловин і крок між ними згідно із запропонованою схемою їх розташування в межах виїмкового стовпа.

Практична значимість. Запропонована схема дегазації вуглепородного масиву дає можливість управляти процесом видобутку шахтного метану, включаючи спеціальні підготовчі операції. Розширюється область ефективного застосування системи вилучення шахтного газу, скорочується час на проведення підготовчих робіт з дегазації, що сприяє як підвищенню навантаження на очисні вибої, так і супутньому видобутку шахтного газу, і за рахунок цього збільшується енергозбереження та безпека ведення гірничих робіт.

Ключові слова: каптачія, метан, вугільний пласт, дегазачія, вуглепородний масив, свердловина

\section{Формирование схемы каптации шахтного метана при разработке газообильных угольных пластов}

\section{Е. Коровяка, Я. Пинка, С. Тимченко, В. Расцветаев, В. Астахов, Е. Дмитрук}

Цель. Обоснование и разработка эффективной схемы каптации шахтного метана при подготовке и отработке газообильных угольных пластов.

Методика. Выполнен критический анализ литературных источников и систематизации опыта применения известных схем каптации шахтного метана для его дальнейшего использования. Произведен анализ и выбор теоретического обоснования новой схемы 
каптации шахтного метана, что, в частности, учитывает показатели подготовки и разработки газообильных угольных пластов. Применены методы математического анализа для описания гамма распределения непрерывной случайной величины интенсивности газовыделения от расстояния до очистного забоя

Результаты. Усовершенствована схема дегазации углепородного массива, в которой, при определенном расположении скважин и введением новых технологических операций и параметров, достигается возможность повышения степени дегазации и удаления шахтного газа, в том числе газа метана. Разработанная схема учитывает физико-механических свойства горных пород за счет чего увеличивается объем добываемого газа при снижении суммарных затрат на добычу полезных ископаемых. Математическим моделированием установлено, что функция плотности распределения максимально совпадает с экспериментально-практическим графиком зависимости интенсивности газовыделения от расстояния до очистного забоя.

Научная новизна. Установлены аналитические зависимости, позволяющие оценить рациональный диапазон глубины дегазационных газоотводящих скважин и шаг между ними согласно предложенной схеме их расположения в пределах выемочного столба.

Практическая значимость. Предлагаемая схема дегазации углепородного массива дает возможность управлять процессом добычи шахтного метана, включая специальные подготовительные операции. Расширяется область эффективного применения системы извлечения шахтного газа, сокращается время на проведение подготовительных работ по дегазации, что способствует как повышению нагрузки на очистные забои, так и сопутствующей добыче шахтного газа, и за счет этого увеличивается энергосбережение и безопасность ведения горных работ.

Ключевые слова: каптация, метан, угольный пласт, дегазация, углепородный массив, скважина

\section{Article info}

Received: 22 January 2020

Accepted: 20 May 2020

Available online: 25 June 2020 